\title{
The effect of a protagonist's emotional shift on situation model construction
}

\author{
HIDETSUGU KOMEDA and TAKASHI KUSUMI \\ Kyoto University, Kyoto, Japan
}

\begin{abstract}
We examined whether readers monitored protagonists' emotional shifts and whether reader engagement influenced situation model construction. Participants read narratives that included an emotional shift in the middle of the story. In Experiment 1, participants were instructed to read stories appreciatively and to empathize with the protagonists. In Experiment 2, readers were instructed to read the stories normally, as if they were reading novels. The results from the two experiments suggest that readers monitor temporal and causal shifts as well as protagonists' emotional shifts in stories. Moreover, in Experiment 1 readers detected temporal and causal shifts regardless of the degree of their engagement during the empathetic reading, while in Experiment 2 the high ego involvement group detected causal shifts during the normal reading. Thus, these results show both that readers monitor protagonists' emotional states and that reader emotional engagement can influence situation model construction with normal reading.
\end{abstract}

When we read stories, we often experience several emotions. For example, even though readers know that the events and characters portrayed in stories are fictitious, they tend to feel happy when positive events occur and to worry when protagonists are in danger. In addition, readers can represent and update a character's emotional state (de Vega, León, \& Díaz, 1996). Readers also make inferences-possibly automatically - about the emotions of protagonists (Gernsbacher, Hallada, \& Robertson, 1998). These studies suggest that readers monitor changes in protagonists' emotions during the online reading process.

Readers' emotions may also be related to the reading process, comprehension difficulty, and their impressions after reading. Emotions experienced during comprehension may be involved in establishing coherent representations. Komeda and Kusumi (2002) used a word association methodology to investigate the emotions that readers experienced. The results indicated that reader surprise decreased at the end of a story, while relief increased as the reader neared the end. Miall (1989) proposed that reader emotion plays the primary role in directing the reading of literary narratives. For example, emotional engagement could help overcome the difficulties of narrative comprehension. Readers not only comprehend stories, but also are engaged by stories.

We thank three anonymous reviewers for their helpful comments on the manuscript. This study was supported by the 21st Century Centers of Excellence program (Program Number D-10 to Kyoto University), MEXT, Japan, and a research fellowship from the Japan Society for the Promotion of Science. Correspondence should be addressed to H. Komeda, c/o T. Kusumi, Department of Cognitive Psychology in Education, Graduate School of Education, Kyoto University, Yoshida-honmachi, Sakyo-ku, Kyoto 6068501, Japan (e-mail:komeda@nips.ac.jp).

Note-This article was accepted by the previous editorial team, when Colin M. MacLeod was Editor.

\section{Protagonists' and Readers' Emotions}

Emotions are part of the narrative experience, and there are at least two aspects to emotion in narratives. First, protagonists in narratives experience emotions. For example, it has been noted that readers are able to monitor the emotional state of protagonists by understanding their actions, goals, and interactions with other characters (Gernsbacher, Goldsmith, \& Robertson, 1992). In their 1996 study, de Vega et al. found that reading times for target sentences were slower when protagonists' reported emotions were inconsistent rather than consistent with the first part of the story, thus demonstrating that readers build situation models - i.e., representations of text - that include protagonists' emotions.

Protagonists' emotional states emerge from the structure of the stories that they are part of. For example, Stein and Levine (1989) showed that when adults and 3- and 6-year-old children predicted protagonists' emotional responses to different types of events, their predictions varied according to whether or not a goal was achieved. That is, when participants were asked to explain why the protagonist would feel the emotion they predicted, they associated the emotion with achievement of a goal. For example, one child said, "Jimmy's happy because he got a toy car." These responses to questions supported the idea that both children and adults used a goal outcome structure to explain why a particular emotional response occurred. Thus causal structure is essential to understanding the representation of a protagonist's emotional state. A character's emotions are manifested when that character experiences an emotional response to the success or failure of a goal (Dijkstra, Zwaan, Graesser, \& Magliano, 1994). Protagonists feel happy when they achieve their goals and sad when they fail. Alternatively, achieving a goal may lead to ambivalent or negative emotional reactions when, for example, a protagonist accomplishes a 
goal that is understood as immoral. In other words, protagonists' emotional states depend on plot and character development as well as on the causal structure mediated by their goals.

Second, a reader's emotions are also a part of the narrative experience. For example, readers monitor and evaluate the concerns of characters during narrative comprehension. Reader evaluations revealed by think aloud protocols included appraisals (good vs. bad), preferences (like vs. do not like), and emotions (happy vs. frustrated) (Özyürek \& Trabasso, 1997).

It has been suggested that a reader's level or type of engagement, such as developing a preference for a particular story outcome, may affect the reader's mental simulations. According to Rapp and Gerrig (2002), readers encode not only the characters' intentions, but also their own preferences about them. Long and Lea (2005) found that a reader's "search for meaning" guides the evaluation of activated information during comprehension and suggested that the reader's evaluation may play a critical role in text comprehension. In a study of comprehension and emotion, Komeda, Nihei, and Kusumi (2005) examined the feelings of anticipation, empathy, and a sense of strangeness. They found that, toward the end of a story, a reader's empathy increases, while the sense of strangeness decreases.

We suggest that there are two aspects to a reader's emotions. First, readers experience emotion when they monitor a protagonist's emotional state. We refer to this as ego involvement. Readers empathize with characters in stories, and a character's emotions and the reader's empathy for that character are strongly related (Dijkstra et al., 1994). The second aspect of a reader's emotion arises from the story's structure. We refer to this as story evaluation. For example, suspense implies that something will happen to the protagonist that he or she is unaware of (Dijkstra et al., 1994). Zillmann (1994) examined identification with dramatic characters and found that the stronger the affective dispositions developed by dramatic events, the stronger the reader's corresponding emotional involvement.

\section{Situation Models and Readers' Emotion}

During narrative comprehension, readers construct representations of text information known as situation models (see, e.g., Gernsbacher, 1990; Graesser, Singer, \& Trabasso, 1994; Kintsch, 1998; van Dijk \& Kintsch, 1983; Zwaan \& Radvansky, 1998). Situation models are coherent mental representations of both text-derived propositions and inferences contributed from long-term memory (Zwaan \& Radvansky, 1998). According to assumptions about situation models, readers are influenced not only by the structure of the text but also by the nature of the situation described therein (Zwaan, 1999b).

Situation models consist of at least five dimensions: time, space, causation, intentionality, and the protagonist (Magliano, Zwaan, \& Graesser, 1999; Zwaan \& Radvansky, 1998). Zwaan, Langston, and Graesser (1995) developed an event-indexing model to explain how readers construct coherent multidimensional representations of situations. According to their model, events and protagonists' actions are important in constructing situation models. During narrative comprehension, readers monitor several dimensions of the situation models and continually update their current model. Recent studies have suggested the possibility of similarity between the forms of situation models and those of autobiographical memory (Magliano, Radvansky, \& Copeland, in press; Zwaan \& Radvansky, 1998). Indeed, Magliano et al. have argued that the self can be conceived as being part of a situation model, and they used the self as a situational component in their analysis of performance in interactive video games.

The event-indexing model does not specify that a reader's emotions in a situation model should be regarded as a separate dimension (Zwaan, 1999a). Zwaan and Radvansky (1998) suggested that emotions should be considered as protagonist characteristics that change as a result of goal success or failure. While we agree that protagonist emotions are a component of the protagonist dimension, we further suggest that readers' emotions during comprehension are also of general importance.

First, a reader's emotions affect situation model construction. Van den Broek, Risden, and Husebye-Hartmann (1995) suggested that readers monitor their current state of comprehension relative to their standards of coherence as they comprehend texts. We suggest that when readers are highly engaged in the comprehension process, they construct situation models more effectively because their standards of coherence become higher. Alternatively, when reader engagement is low, it is less likely that they will construct an elaborate situation model because of lower standards of coherence.

Second, a reader's emotions are an important component of comprehension. Situation models consist not only of general semantic knowledge but also of personal components, such as a reader's emotional state and individual experiences (Kintsch, 1998). The event-indexing model, as it is, describes a reader's knowledge of a situation, but does not incorporate the reader's involvement in it. It is important to understand a reader's emotional state during the process of narrative comprehension, because the process is similar to the process of understanding real life emotional experiences.

\section{General Overview of the Experiments}

The first objective of this study is to show that shifts in the emotional state of a protagonist influence the online reading process. We tested whether sentence-reading times increased during the reading of a story as a result of a shift in the protagonist's emotions. We examined whether the protagonist's emotional shift led readers to process the texts in a way similar to how readers process other textual dimensions. We also assessed other dimensions (temporal, causal, and spatial) studied by previous researchers using new texts in a new language (Japanese) and adopting the assumptions of the event-indexing model. According to previous studies (Zwaan, Magliano, \& Graesser, 1995; Zwaan, Radvansky, Hilliard, \& Curiel, 1998), multiple-regression analyses of increased reading times revealed that readers monitored 
both temporal and causal continuity; that is, discontinuities in these dimensions led to significant increases in reading times as readers updated the situation model.

The second objective was to study how a reader's engagement influenced situation model construction. A reader's ego involvement (which includes empathy with the protagonist as well as a reader's past experience) and evaluation of a story (involving a reader's interest and the story's readability) are assessed in this study. We used ego involvement and evaluation scales to investigate the relationship between each dimension of a situation model and the experienced emotion of readers. If situation models can be viewed as a form of autobiographical memory (Magliano et al., in press), then the idea that the self is emotionally involved in situation model processing is important. Moreover, the effect of a story's evaluation is also important. When readers evaluate a story highly, this may be because they have constructed a rich situation model. We studied whether readers who were more strongly engaged in a story would be more sensitive to shifts in the dimensions of a situation model, specifically the protagonists' emotional shifts.

The ego involvement scale consisted of the following three items: the reader's empathy with the protagonists, the similarity of the reader's thoughts and behaviors to the protagonist's, and the similarity of the reader's past experience to the story events. The evaluation scale used ratings to measure reader responses after narrative comprehension. The evaluation scale measured the reader's interest in the story's theme and the story's readability.

Experiments 1 and 2 differed in the instructions given to the participants. In Experiment 1, participants were instructed to read the stories to appreciate them and to empathize with the protagonists. Participants were expected to focus on the protagonists' emotions. In Experiment 2, participants were instructed to focus on the stories normally, as if they were reading novels, following Zwaan, Magliano, and Graesser's (1995) normal reading condition.

\section{EXPERIMENT 1}

\section{Method}

Participants. Thirty-six undergraduate and graduate students from Kyoto University participated in Experiment 1 for compensation equivalent to 200 yen (about \$2). All of the participants were native Japanese speakers.

Materials. We constructed 16 stories, which included four emotional states - worry-relief, relief-worry, worry-worry, and reliefrelief - and four themes, which represented topics familiar to university students: examinations, moving, parties, and marriage. Each story had only one protagonist, to make it easier for readers to empathize with the protagonist and to control for the effects of other characters. Two sample stories used in our experiments are presented in Appendixes A and B. We manipulated an emotional shift in the middle of each story. One emotional shift consisted of the protagonist's being worried during the first half of the story and relieved in the second half (worry-relief). Another version portrayed the protagonist as feeling relieved during the first half and worried in the second (relief-worry). The other versions of the stories consisted of worry-worry and reliefrelief emotional states. There were 24 sentences in each story. Presentation of the story versions was counterbalanced with a $4 \times 4$ Latin square design. Each participant read four stories.
Situational shifts, such as time, causality, and space, were classified as dichotic variables based on previous studies (Zwaan, Magliano, \& Graesser, 1995; Zwaan et al., 1998). Emotional shifts were coded similarly. Each story had six sentences with emotional shifts. Samples of each shift type appear in Appendixes A and B.

The stories were also analyzed in terms of text-based characteristics, such as number of text characters and serial position of sentences. Number of characters is an indication of the length of the sentences and corresponds to number of syllables used in previous English language studies (Zwaan, Magliano, \& Graesser, 1995; Zwaan et al., 1998). In Japanese, each kana character is equivalent to a syllable. Japanese kanji, hiragana, and katakana characters were used in this study (see Appendixes). The serial position of sentences was also treated as a text-based variable (see, e.g., Zwaan, Magliano, \& Graesser, 1995). The situational variables were analyzed by a trained judge, who used the coding scheme found in Zwaan et al. (1998). A second trained judge provided an independent analysis of the four stories. Concurrence between the judges was consistently very high (93.8\%) and discrepancies were resolved through discussion.

Procedure. The participants were instructed to read the stories to appreciate them and to empathize with the protagonists. Before the test session, the participants read a short story to familiarize themselves with the reading procedure. During the test session, stories were presented one sentence at a time on a computer screen. Each sentence remained on the screen until the participant pressed the space bar, and then the next sentence appeared. The computer measured reading times for each sentence.

After the participants read each story, an instruction appeared on the screen telling them to rate their offline responses on five 7-point scales (empathy, similarity between the protagonist and the reader, experience, interest in the theme, and readability of the story). For empathy ratings, participants were asked, "How well could you enter into the protagonist's emotion?" The question to elicit similarity ratings was: "How similar are your own thoughts and behavior to those of the protagonist?" Experience ratings were elicited by "How similar are your own past experiences to those presented here?" Responses to "How interested were you in the theme of the story?" provided participants' interest ratings. The question for the readability rating was: "How readable did you find the story?" The experiment lasted approximately $25 \mathrm{~min}$.

\section{Results and Discussion}

Table 1 displays the bivariate correlations between pairs of predictor variables. The correlations were generally low, consistent with those found by Zwaan et al. (1995) and Zwaan et al. (1998).

We performed multiple regression analyses on the reading times to assess the influence of temporal, causal, spatial, and emotional shifts. Table 2 presents the beta weights; single-sample $t$ tests were used to examine whether the weights were significantly different from zero, based on Lorch and Myers (1990). As Table 2 indicates, sentences that had a greater number of characters and an earlier serial position within the story caused reading times to increase, as in previous studies (e.g., Zwaan, Magliano, \& Graesser, 1995). Temporal and causal shifts also caused sentence-reading times to increase, suggesting that readers took extra time to update their situation model. However, spatial shifts did not increase reading times. The failure to find an influence of spatial shifts is consistent with Zwaan, Magliano, and Graesser's study (1995). Importantly, emotional shifts also caused reading times to increase. These results indicate that, during the online reading process, readers monitored each story's 
Table 1

Bivariate Correlations Between Predictor Variables in Experiments 1 and 2

\begin{tabular}{lcccccc}
\hline \multicolumn{1}{c}{ Variables } & 1 & 2 & 3 & 4 & 5 & 6 \\
\hline 1. Number of characters & - & & & & & \\
2. Serial position & $.17^{* *}$ & - & & & & \\
3. Temporal shifts & -.07 & -.04 & - & & & \\
4. Causal shifts & .01 & -.10 & $.25^{* *}$ & - & & \\
5. Spatial shifts & .06 & $.14^{* *}$ & $.61^{* *}$ & $.15^{* *}$ & - & \\
6. Emotional shifts & $.17^{* *}$ & $.34^{* *}$ & $-.17^{* *}$ & $-.15^{* *}$ & -.05 & - \\
${ }^{* *} p<.01 . \quad N=368$. & & & & & &
\end{tabular}

temporal, causal, and emotional dimensions, including the protagonist's emotional shifts, and then updated their situation models accordingly.

Table 3 presents the bivariate correlations between the engagement ratings. Empathy correlated significantly with similarity and experience, and similarity correlated significantly with experience; these three variables were collapsed to form the ego involvement scale. Interest correlated significantly with readability; these two variables were collapsed to form the evaluation scale. Mean ratings were as follows: empathy $5.44(S D=1.35)$, similarity $4.09(S D=1.83)$, experience $3.26(S D=2.07)$, interest $4.48(S D=1.58)$, and readability $4.27(S D=1.52)$.

We classified participants as belonging to a high or a low group according to their ego involvement and evaluation scores. Data from participants whose scores were closest to the average of both scores were discarded; $6.9 \%$ of the participants were thus removed. The average ego involvement score was $4.26(S D=0.61)$. Scores for the highinvolvement group $(n=18)$ ranged from 4.33 to 5.17 , and scores for the low-involvement group $(n=15)$ ranged from 2.83 to 4.17 . The average evaluation score was $4.38(S D=$ $1.03)$. Scores for the high-evaluation group $(n=17)$ ranged from 4.50 to 6.25 , and scores for the low-evaluation group $(n=17)$ ranged from 1.88 to 4.25 .

Next, we assessed the multiple regression analyses of each group to investigate the effects of ego involvement and story evaluation on situation model construction (Table 4). We performed significance tests to see whether there was a difference between high and low groups on the basis of each beta weight. No differences in temporal $(t=1.09, p=.28)$, causal $(t=-0.40, p=.69)$, spatial $(t=0.68, p=.50)$, or emotional shifts $(t=-0.93, p=$ $.36)$ were found between the groups in ego involvement. Similarly, no differences in temporal $(t=1.63, p=.11)$,

Table 2

Beta Weights From the Regression Analyses of Reading Times in Experiments 1 and 2

\begin{tabular}{lcrlrr}
\hline \multirow{2}{*}{ Variables } & \multicolumn{2}{c}{ Experiment 1} & & \multicolumn{2}{c}{ Experiment 2} \\
\cline { 2 - 3 } \cline { 6 - 6 } \multicolumn{1}{c}{} & \multicolumn{1}{c}{$\beta$} & \multicolumn{1}{c}{$t$} & & $\beta$ & \multicolumn{1}{c}{$t$} \\
\hline Number of characters & $.420^{* * *}$ & 21.11 & & $.429^{* * *}$ & 16.50 \\
Serial position & $-.193^{* * *}$ & -7.07 & & $-.214^{* * *}$ & -5.76 \\
Time & $.088^{* * *}$ & 4.76 & & $.104^{* *}$ & 3.79 \\
Causation & $.068^{* * *}$ & 5.27 & & $.065^{* * *}$ & 4.34 \\
Space & -.019 & -1.09 & & $-.052^{*}$ & -2.70 \\
Emotion & $.064^{* *}$ & 3.09 & & $.077^{* *}$ & 2.83 \\
\hline
\end{tabular}

${ }^{*} p<.05 . \quad{ }^{* *} p<.01 . \quad{ }^{* * *} p<.001$. Two-tailed. causal $(t=0.81, p=.43)$, spatial $(t=-0.27, p=.79)$, or emotional shifts $(t=0.21, p=.84)$ were found between the groups in story evaluation.

In summary, readers monitored temporal and causal shifts and, importantly, protagonists' emotional changes. When analyzing differences between the groups with respect to ego involvement and evaluation, we found that both groups of readers detected temporal and causal shifts. Although the effect of emotional shifts differed on the ego involvement and the evaluation scales, the differences between high and low groups were not significant.

Readers do not always empathize with protagonists when stories are read in an ordinary fashion. The case of the empathetic reading in Experiment 1 may, therefore, be special. Because the specific reading instructions may have influenced the results in Experiment 1, participants were instructed to read normally in Experiment 2.

\section{EXPERIMENT 2}

\section{Method}

Participants. Twenty-eight undergraduate and graduate students from Kyoto University participated in Experiment 2 for compensation equivalent to two hundred yen (about \$2). All of them were native Japanese speakers, and none of them had participated in Experiment 1.

Materials and Procedure. The materials and procedure were similar to those used in Experiment 1. However, the participants were instructed to read the stories normally, as if reading a novel. This reading instruction followed Zwaan, Magliano, and Graesser's (1995) normal reading condition. In contrast to Experiment 1, the participants were not urged to empathize with the protagonists.

\section{Results and Discussion}

As Table 2 indicates, the results of both text-based factors (number of text characters in and the serial positions of sentences) and situational factors (temporal, causal, and emotional shifts) replicated those of Experiment 1.

Table 5 presents the bivariate correlations between the engagement ratings. Empathy correlated significantly with similarity and experience. Similarity correlated significantly with experience. Therefore, these ratings were reliably intercorrelated. Since interest correlated significantly with readability, these ratings were also reliably intercorrelated. These variables were collapsed to form the ego involvement and the evaluation scales, as in Experiment 1 . Mean ratings were as follows: empathy 5.40 $(S D=1.32)$, similarity $4.05(S D=1.79)$, experience 3.45 $(S D=2.05)$, interest $4.43(S D=1.44)$, and readability $4.29(S D=1.43)$; these ratings are similar to those ob- 
Table 3

Correlations Between Pairs of Each Rating in Experiment 1

\begin{tabular}{|c|c|c|c|c|c|}
\hline \multirow[b]{2}{*}{ Ratings } & \multicolumn{3}{|c|}{ Ego Involvement Scale } & \multicolumn{2}{|c|}{ Evaluation Scale } \\
\hline & 1 & 2 & 3 & 4 & 5 \\
\hline 1. Empathy & - & & & & \\
\hline 2. Similarity & $.56^{* *}$ & - & & & \\
\hline 3. Experience & $.46^{* *}$ & $.55^{* *}$ & - & & \\
\hline 4. Interest & $.26^{* *}$ & $.22^{* *}$ & $.26^{* *}$ & - & \\
\hline 5. Readability & $.17^{*}$ & .14 & $.14^{\dagger}$ & $.54^{* *}$ & - \\
\hline
\end{tabular}

Table 4

Standardized Regression Coefficients (Beta Weights) in Each Group of Both Scales in Experiment 1

\begin{tabular}{|c|c|c|c|c|c|c|c|c|}
\hline \multirow[b]{3}{*}{ Variables } & \multicolumn{4}{|c|}{ Ego Involvement Scale } & \multicolumn{4}{|c|}{ Evaluation Scale } \\
\hline & \multicolumn{2}{|c|}{$\operatorname{High}(n=18)$} & \multicolumn{2}{|c|}{ Low $(n=15)$} & \multicolumn{2}{|c|}{$\operatorname{High}(n=17)$} & \multicolumn{2}{|c|}{ Low $(n=17)$} \\
\hline & $\beta$ & $t$ & $\beta$ & $t$ & $\beta$ & $t$ & $\beta$ & $t$ \\
\hline Time & $.105^{* *}$ & 4.09 & $.063^{*}$ & 2.24 & $.121^{* * *}$ & 4.40 & $.059^{*}$ & 2.22 \\
\hline Causation & $.066^{* * *}$ & 4.56 & $.078^{*}$ & 3.00 & $.072^{* *}$ & 4.30 & $.051^{*}$ & 2.63 \\
\hline Space & -.011 & -0.539 & -.036 & -1.07 & -.020 & -0.838 & -.012 & -0.584 \\
\hline Emotion & .046 & 1.51 & $.088^{*}$ & 2.66 & $.064^{*}$ & 2.29 & .055 & 1.69 \\
\hline
\end{tabular}

tained in Experiment 1. Thus no influence of instruction was found.

We classified the participants as being in a high or a low group according to their ego involvement and evaluation scores. Data from participants whose scores were closest to the average of both scores were discarded; $3.6 \%$ were thus removed. The average ego involvement score was $4.30(S D=0.55)$. Scores for the high-involvement group $(n=13)$ ranged from 4.42 to 5.33 , and scores for the lowinvolvement group $(n=14)$ ranged from 3.08 to 4.25 . The average evaluation score was $4.36(S D=0.79)$. Scores for the high-evaluation group $(n=13)$ ranged from 4.50 to 6.00 and scores for the low-evaluation group $(n=14)$ ranged from 2.50 to 4.25 .

We assessed multiple regression analyses for each group (Table 6). We performed significance tests to see whether there was a difference between the high and the low groups. The high-involvement group detected causal shifts more strongly than did the low-involvement group $(t=2.13, p=.04)$. Other differences in temporal $(t=$ $-1.68, p=.11)$, spatial $(t=1.81, p=.08)$, and emotional shifts $(t=1.18, p=.25)$ did not significantly differ between the ego involvement groups. No differences in temporal $(t=0.57, p=.58)$, causal $(t=-0.13, p=$

Table 5

Correlations Between Pairs of Each Rating in Experiment 2

\begin{tabular}{lcccccc}
\hline & \multicolumn{3}{c}{ Ego Involvement Scale } & & \multicolumn{2}{c}{ Evaluation Scale } \\
\cline { 2 - 3 } \multicolumn{1}{c}{ Ratings } & 1 & 2 & 3 & & 4 & 5 \\
\hline 1. Empathy & - & & & & \\
2. Similarity & $.69^{* *}$ & - & & & \\
3. Experience & $.43^{* *}$ & $.55^{* *}$ & - & & \\
4. Interest & -.03 & .06 & -.09 & & - & \\
5. Readability & .04 & .04 & .01 & & $.59^{* *}$ & - \\
\hline
\end{tabular}

${ }^{*} p<.05 . \quad{ }^{* *} p<.01 . \quad N=112$.
$.90)$, spatial $(t=-0.79, p=.44)$, or emotional shifts $(t=-1.24, p=.23)$ were found between the groups on story evaluation. The detection of temporal, spatial, and emotional shifts in normal reading were not strongly influenced by readers' ego involvement and evaluation of stories. However, the high-involvement group could detect causal shifts during normal reading.

On the whole in Experiment 2, readers monitored temporal and causal shifts as well as protagonists' emotional changes, much as they did in Experiment 1. Moreover, when we analyzed individual differences, we found that the highinvolvement group was more likely to detect causal shifts during normal reading than the low-involvement group.

\section{GENERAL DISCUSSION}

The first objective of this study was to examine the effect of protagonists' emotional shifts on the online reading process. Emotional shifts caused reading times to increase under both reading instructions. This indicates that the effect of an emotional shift is reliable and that readers likely update their situation models as they experience a protagonist's emotional shift.

We also examined the effects of a story's temporal, causal, and spatial dimensions on the situation model in relation to the assumptions of the event-indexing model. In Experiments 1 and 2, we replicated previous studies (Zwaan, Magliano, \& Graesser, 1995; Zwaan et al., 1998) by showing that temporal and causal shifts increased reading times under both empathetic and normal readings. No effect of spatial shifts was detected in the experiments. It is relatively difficult to detect spatial shifts in normal reading (see, e.g., Zwaan, Magliano, \& Graesser, 1995; Zwaan et al., 1998). This may be because the spatial inference is made on the condition that it provide causal 
Table 6

Standardized Regression Coefficients (Beta Weights) in Each Group of Both Scales in Experiment 2

\begin{tabular}{|c|c|c|c|c|c|c|c|c|}
\hline \multirow[b]{3}{*}{ Variables } & \multicolumn{4}{|c|}{ Ego Involvement Scale } & \multicolumn{4}{|c|}{ Evaluation Scale } \\
\hline & \multicolumn{2}{|c|}{$\operatorname{High}(n=13)$} & \multicolumn{2}{|c|}{ Low $(n=14)$} & \multicolumn{2}{|c|}{$\operatorname{High}(n=13)$} & \multicolumn{2}{|c|}{ Low $(n=14)$} \\
\hline & $\beta$ & $t$ & $\beta$ & $t$ & $\beta$ & $t$ & $\beta$ & $t$ \\
\hline Time & .057 & 1.15 & $.150^{* * *}$ & 5.70 & $.117^{* *}$ & 3.40 & $.085^{\dagger}$ & 1.89 \\
\hline Causation & $.098^{* * *}$ & 6.23 & .036 & 1.51 & $.063^{* *}$ & 3.20 & $.067^{*}$ & 2.80 \\
\hline Space & -.004 & -0.112 & $-.079^{* *}$ & -3.41 & $-.065^{\dagger}$ & -2.00 & -.030 & -1.03 \\
\hline Emotion & $.116^{*}$ & 2.73 & .052 & 1.49 & .053 & 1.57 & $.117^{*}$ & 2.95 \\
\hline
\end{tabular}

information that is important to a reader's comprehension (Radvansky \& Copeland, 2000; Sundermeier, van den Broek, \& Zwaan, 2005).

The second objective of this study was to examine whether situational shifts were influenced by the readers' engagement. The empathetic reading of Experiment 1 suggested that neither reader ego involvement nor story evaluation influenced the reader's ability to detect situational shifts. Readers may construct a "maximalist situation model" (Zwaan, Magliano, \& Graesser, 1995) due to empathy with the protagonists. Alternatively, the effect of the individual differences, found with normal reading in Experiment 2, suggested that the higher their ego involvement, the easier it was for readers to detect causal shifts. Therefore, readers' emotional engagement may influence situation model construction in normal reading. However, there were no differences between the responses of the high-involvement group and those of the low-involvement group in the detection of temporal and spatial dimensions in the situation model.

In conclusion, an expansion of the online processing model of situation model construction should consider the role of reader engagement, including emotional engagement, in narrative comprehension. According to the landscape model (van den Broek \& Gustafson, 1999; van den Broek, Young, Tzeng, \& Linderholm, 1999), meaningful components, such as emotion, depend on the reader's standards for coherence. Van den Broek and Kendeou (2004) employed the landscape model to explain emotions in narratives as complex situations. The event-indexing model will more completely represent the online reading process when readers' different levels of engagement are appropriately integrated into it.

\section{REFERENCES}

DE Vega, M., León, I., \& Diáz, J. M. (1996). The representation of changing emotions in reading comprehension. Cognition \& Emotion, 10, 303-321.

Dijkstra, K., Zwann, R. A., Graesser, A. C., \& Magliano, J. P. (1994). Character and reader emotions in literary texts. Poetics, 23, 139-157.

GERNSBACHER, M. A. (1990). Language comprehension as structure building. Hillsdale, NJ: Erlbaum.

Gernsbacher, M. A., Goldsmith, H. H., \& Robertson, R. R. W. (1992). Do readers mentally represent characters' emotional states? Cognition \& Emotion, 6, 89-111.

Gernsbacher, M. A., Hallada, B. M., \& Robertson, R. R. W. (1998). How automatically do readers infer fictional characters' emotional states? Scientific Studies of Reading, 2, 271-300.
Graesser, A. C., Singer, M., \& Trabasso, T. (1994). Constructing inferences during narrative text comprehension. Psychological Review, 101, 371-395.

KINTSCH, W. (1998). Comprehension: A paradigm for cognition. Cambridge: Cambridge University Press.

Komeda, H., \& Kusumi, T. (2002). Reader's changing emotions related to the construction of a situation model. Tohoku Psychologica Folia, 61, 48-54.

KomedA, H., Nihei, Y., \& Kusumi, T. (2005). The roles of reader's feelings in understanding narratives: Forefeel, empathy, and a sense of strangeness [In Japanese with English abstract]. Japanese Journal of Psychology, 75, 479-486.

LONG, D. L., \& LEA, R. B. (2005). Have we been searching for meaning in all the wrong places? Defining the "search after meaning" principle in comprehension. Discourse Processes, 39, 279-298.

LORCH, R. F., JR., \& Myers, J. L. (1990). Regression analyses of repeated measures data in cognitive research. Journal of Experimental Psychology: Learning, Memory, \& Cognition, 16, 149-157.

Magliano, J. P., Radvansky, G. A., \& Copeland, D. E. (in press). Beyond language comprehension: Situation models as a form of autobiographical memory. In F. Schmalhofer \& C. A. Perfetti (Eds.), Higher level language processes in the brain: Inference and comprehension processes. Mahwah, NJ: Erlbaum.

Magliano, J. P., ZwaAn, R. A., \& Graesser, A. (1999). The role of situational continuity in narrative understanding. In H. van Oostendorp \& S. R. Goldman (Eds.), The construction of mental representations during reading (pp. 219-245). Mahwah, NJ: Erlbaum.

Miall, D. S. (1989). Beyond the schema given: Affective comprehension of literary narratives. Cognition \& Emotion, 3, 55-78.

ÖZyüreK, A., \& Trabasso, T. (1997). Evaluation during the understanding of narratives. Discourse Processes, 23, 305-335.

RADVANSKY, G. A., \& Copeland, D. E. (2000). Functionality and spatial relations in memory and language. Memory \& Cognition, 28, 987992.

RAPP, D. N., \& GerRIG, R. J. (2002). Readers' reality-driven and plotdriven analyses in narrative comprehension. Memory \& Cognition, 30, 779-788.

StEIN, N. L., \& LEvine, L. J. (1989). The causal organization of emotional knowledge: A developmental study. Cognition \& Emotion, 3, 343-378.

Sundermeier, B. A., van den Broek, P., \& ZwaAn, R. A. (2005). Causal coherence and the availability of locations and objects during narrative comprehension. Memory \& Cognition, 33, 462-470.

van den Broek, P., \& Gustafson, M. (1999). Comprehension and memory for texts: Three generations of reading research. In S. R. Goldman, A. C. Graesser, \& P. van den Broek (Eds.), Narrative comprehension, causality, and coherence: Essays in honor of Tom Trabasso (pp. 15-34). Mahwah, NJ: Erlbaum.

van den Broek, P., \& Kendeou, P. (2004, August). About inferences and representations: Simulating reading comprehension in various circumstances using the landscape model. Paper presented at the 14th annual meeting of the Society for Text and Discourse, Chicago.

van den Broek, P., Risden, K., \& Husebye-Hartmann, E. (1995). The role of readers' standards for coherence in the generation of inferences during reading. In R. F. Lorch, Jr. \& E. J. O’Brien (Eds.), Sources of coherence in reading (pp. 353-373). Hillsdale, NJ: Erlbaum. 
van den Broek, P., Young, M., Tzeng, Y., \& Linderholm, T. (1999). The landscape model of reading: Inferences and the online construction of a memory representation. In H. van Oostendorp \& S. R. Goldman (Eds.), The construction of mental representations during reading (pp. 71-98). Mahwah, NJ: Erlbaum.

VAN DiJK, T. A., \& KinTsch, W. (1983). Strategies of discourse comprehension. New York: Academic Press.

ZillmanN, D. (1994). Mechanisms of emotional involvement with drama. Poetics, 23, 33-51.

ZWAAN, R. A. (1999a). Five dimensions of narrative comprehension: The event-indexing model. In S. R. Goldman, A. C. Graesser, \& P. van den Broek (Eds.), Narrative comprehension, causality, and coherence: Essays in honor of Tom Trabasso (pp. 93-110). Mahwah, NJ: Erlbaum.
ZWAAn, R. A. (1999b). Situation models: The mental leap into imagined worlds. Current Directions in Psychological Science, 8, 15-18.

ZwaAn, R. A., LANGSTON, M. C., \& Graesser, A. C. (1995). The construction of situation models in narrative comprehension: An eventindexing model. Psychological Science, 6, 292-297.

Zwaan, R. A., Magliano, J. P., \& Graesser, A. C. (1995). Dimensions of situation model construction in narrative comprehension. Journal of Experimental Psychology: Learning, Memory, \& Cognition, 21, 386-397.

ZWAAN, R. A., \& RADVANSKY, G. A. (1998). Situational models in language comprehension and memory. Psychological Bulletin, 123, 162-185.

Zwaan, R. A., Radvansky, G. A., Hilliard, A. E., \& Curiel, J. M. (1998). Constructing multidimensional situation models during reading. Scientific Studies of Reading, 2, 199-220. 


\section{APPENDIX A \\ Sample Japanese Text in Worry-Relief Version, With English Translation}

Temporal shifts occur in Sentences 2, 7, 9, 11, 13, 16, 17, and 20. Causal shifts occur in Sentences 2, $3,4,6,7,9,10,11,13,14,16,17,18,19,20,21,22$, and 23. Spatial shifts occur in Sentences 11, 17, and 20. The protagonist's emotional shifts occur in Sentences 14, 15, 17, 18, 19, and 24.

1. 今日も勉強しないまま一日が終わってしまった.

(I had not studied at all and the day had passed.)

2. 朝になって，昨日の深酒を今さらながら後悔した。

(In the morning, waking up with a hangover, I would regret drinking too much the night before.)

3.ぼんやりとした頭で, 明日の試験のことを考えた.

(I was lost in thought about tomorrow's exam.)

4. 明日の試験は，非常に大事な試験である.

(Tomorrow's exam was very important.)

5.したがって，なんとか合格しなくてはならない.

(Therefore, I had to pass the exam.)

6. 焦ってはみたものの, どうしても勉強が手につかない.

(However, I could not concentrate on my study.)

7. しばらくして，なつかしい友人から電話がかかってきて，今夜会わないかと誘われた。 (After a while, old friends telephoned to ask me to meet them that night.)

8. 再会の喜びに胸おどらせ，友人と食事に行く用意をはじめた.

(As I was glad of the invitation, I got dressed for dinner.)

9. 試験の朝がやってきた.

(The morning of the exam arrived.)

10. 今まで勉強しなかったことを激しく後悔しながらも，学校に行く準備をした。

(Although I regretted that I had not studied, I prepared for school.)

11. 学校に着くと，周りの友人は，まったく勉強していないと口及に言っている. (In the classroom, my classmates told me that they had not prepared for the exam.)

12. それを聞いて少しは落ち着きながら，なんとかべストをつくすことを考えた. (Their conversation relaxed me, so I thought that I would try my best.)

13. 試験問題が配られ，目を通してみて，あ然とした。 (When I saw the exam questions, I was surprised.)

14. 問題が，まさかこれほど易しいとは予想外だった。 (Unexpectedly, the questions were very easy.)

15. 最後まで夕ても，答えられない問題は見当たらなかった.

(I thought that I could answer all of the questions.)

16. 空欄をうめているとあっというまに, 試験終了の合図がなった.

(As soon as I had completed my papers, the exam finished.)

17. 試験から，すぐに一週間が過ぎた。

(The week after the exam passed quickly.)

18.この一週間は, 毎日とても楽しかった. (I enjoyed the week very much.)

19. あんなに試験が易しいのなら，勉強しなくて良かったなと思った。 (As I had not studied, I was lucky that the exam was very easy.)

20. 一時間ほど経って学校に着くと, 掲示板に合格者の番号が貼りだされていた. (When I arrived at school an hour later, the results were up on the board.)

21. 掲示板の前に，クラスの友人が集まっているのが見えた. (Many of my classmates were in front of the board.)

22.テストのときに，まったく勉強していないと言っていた友人たちだ.

(They were the friends who told me that they had not studied.)

23. 彼らのほとんどが，合格していた。

(Most of them had passed.)

24.ますます安心して，自分の番号を探そうと掲示板に目を走らせ，ほっとした， (When I felt up to it, I checked my exam results.) 


\section{APPENDIX B}

Sample Japanese Text in Relief-Worry Version, With English Translation

The situational and emotional shifts occur in the same places as in Appendix A.

1. 今日も本当によく勉強して一日が過ぎていった.

(I had studied a lot and the day had passed.)

2. 朝になって，昨日の徹夜がだんだんこたえてきた.

(In the morning, I would regret that I had stayed up the night before.)

3.ぼんやりとした頭で，明日の試験のことを考えた。

(I was lost in thought about tomorrow's exam.)

4. 明日の試験は, 非常に大事な試験である.

(Tomorrow's exam was very important.)

5. したがって，なんとか合格しなくてはならない.

(Therefore, I had to pass the exam.)

6. でも，勉強してきたのだからきっと合格できるだろう。

(I should pass it, as I had studied very hard.)

7. しばらくして，なつかしい友人から電話がかかってきて，今夜会わないかと誘われた. (After a while, some old friends telephoned to ask me to meet them that night.)

8. 再会の喜びに胸おどらせたが，試験を考え，泣く泣く断った。

(Though I was glad of the invitation, I declined.)

9. 試験の朝がやってきた.

(The morning of the exam arrived.)

10. 今まであんなに勉強してきたことを考えると，不安はほとんど感じなかった．

(Because I had studied very hard, I did not feel at all uneasy.)

11. 学校に着くと，周りの友人は，まったく勉強していないと口及に言っている. (In the classroom, my classmates told me that they had not prepared for the exam.)

12. それを聞いてますます安心しながら，とりあえずベストをつくそうと思った。

(Their conversation relaxed me, and I thought that I had the opportunity to do my best.)

13. 試験問題が配られ，目を通してみて，あ然とした。

(When I saw the exam questions, I was surprised.)

14. 問題が，まさかこれほど難しいとは予想外だった。

(Unexpectedly, the questions were very difficult.)

15. できそうな問題を探すのに，とても苦労するほどだった。

(I thought that I would be unable to answer any of the questions.)

16. 空欄をうめているとあっというまに，試験終了の合図がなった.

(As soon as I had completed my papers, the exam finished.)

17. 悪夢の試験から，一週間が過ぎた。

(After the bad day of the exam, a week passed quickly.)

18.この一週間は，毎日とても心配だった。

(I felt very uneasy all week.)

19. あんなに試験が難しいのなら，もう少し勉強しておくべきだった。

(As the exam had been very difficult, I studied much harder.)

20. 一時間ほど経って学校に着くと，掲示板に合格者の番号が貼りだされていた。

(When I arrived at school an hour later, the results were up on the board.)

21. 掲示板の前に, クラスの友人が集まっているのが見えた.

(Many of my classmates were in front of the board.)

22.テストのときに，まったく勉強していないと言っていた友人たちだ.

(They were the friends who told me that they had not studied.)

23. 彼らのほとんどが, 合格していた。

(Most of them had passed.)

24. ますます不安になり，自分の番号を探そうと揭示板に目を走らせ愕然とした. (I felt uneasy; I was disappointed by my failure in the exam.) 